\title{
Development of Structural Concrete with Partial Replacement of Fine Aggregate by Plastic Waste
}

\author{
Dr. Shanthala B $B^{1}$, Mithesh Kumar, Jagadisha ${ }^{3}$ \\ Assistant Professor, Department of Civil Engineering \\ Government Engineering College, Karwar, Karnataka.
}

\begin{abstract}
Plastic waste is silent threat to the environment and their disposal is a serious issue for waste managers. Now a day society does not have any alternative to plastic products like plastic bags, plastic bottles, and plastic sheets etc. In spite of all efforts made to limit its use but unfortunately its utility is increasing day by day. To circumvent this issue many efforts were made in the past to reuse the plastic waste but no significant results were achieved. On contrary concrete being the widely used construction material is facing problem due to unavailability of construction material (Cement, sand and coarse aggregate). Various attempts were made through experimentation to check the feasibility of plastic waste to be use partially in concrete with respect to various properties of strength, workability, durability and ductility of concrete. This paper includes review of various studies conducted on utility of waste plastic material used in the concrete. Moreover, this paper will draw our focus toward the impingement on the various properties of concrete when partially replacing with waste plastic.In the lab concrete was mixed, cast, cured and tested. The fresh concrete was tested for slump test and the compaction factor test, while the hardened concrete for compressive, tensile and flexural strength. There were four batches, the control and 10\%, 30\% and 50\% weight replacement of sand with granulated plastic. It is found that use of plastic aggregates results in the formation of light weight concrete. The compressive, as well as tensile strength of concrete reduces with the introduction of plastics. The most important change brought about by the use of plastics is that the thermal conductivity of concrete is reduced by using plastics in concrete. It can be said that recycled plastics can be used for thermal insulation of buildings.
\end{abstract}

Key Words: Concrete, Plastic waste, Compressive Strength

\section{I.INTRODUCTION}

A substantial growth in the consumption of plastic is observed all over the world in recent years, which has lead to huge quantities of plastic-related waste. Recycling of plastic waste to produce new materials like concrete or mortar appears as one of the best solutions for disposing of plastic waste, due to its economic and ecological advantages In Kenya, most industrial and domestic activities are associated with significant amounts of nonbiodegradable solid waste, which include a wide range of plastic waste. The research study to be undertaken intended to determine the efficiency of reusing waste plastic in production of concrete.

Utilization of these waste materials is a partial solution to environmental and ecological problems. Use of plastic not only helps in getting them utilized in concrete, it helps in reducing the cost of concrete making, numerous indirect benefits such as reduction landfill cost, saving energy, and protecting the environment from possible pollution effects.

At a time when landfill space is becoming almost impossible due to increasing land value, then recycling and reuse of wastes as beneficial products should be strongly encouraged and examined. One potentially strong and viable market is to develop recyclable wastes into granular aggregates, a common material used throughout the construction industry. The reuse of waste materials in building construction is a great idea, and the high demand for construction materials makes them a favourable medium in which to reuse recyclable materials.

Aggregates are used in a variety of building applications, and can be said to be the largest quantity of material used in any industry. Almost all aggregates are produced from natural resources such as gravel pits, river beds and rock quarries. In addition to depleting these natural resources, mining for aggregates also poses serious environmental risks like disturbance of natural habitats and creating open areas with no vegetation.

Most concrete structures are produced using normal weight aggregates. However, there are certain instances where light weight concrete is desirable, raising the need for partial or total replacement of the aggregate with a lighter substitute. Plastic recycling efforts have increased but are still insufficient. The preferred plastic material for use as an aggregate should be available in large quantities such as post-consumer wastes which has little or no resale value.

The evolution of concrete mix production has taken massive steps over the years. During this period, various types of aggregates have been used. The major role of aggregates in concrete is to provide strength. In instances where light weight concrete is required, a lighter aggregate made from plastic can be adopted.

\section{LITERATURE REVIEW}

Zainab Z. Ismail et al. [2007] they have conducted comprehensive study based on large number of experiments and tests in order to determine the feasibility of reusing plastic sand as partial replacement of fine aggregate in concrete. They conducted tests on concrete samples for dry/fresh density, slump, compressive and flexural strength and finally toughness indices on room temperature They have collected waste plastic from plastic manufacture plant consist of $80 \%$ polyethylene and $20 \%$ polystyrene which was crushed (varying length of $0.15-12 \mathrm{~mm}$ and width of $0.15-4 \mathrm{~mm}$ ). Concrete mix were producing with ordinary Portland cement, fine aggregate (natural sand of $4.74 \mathrm{~mm}$ maximum size), coarse aggregate ( $\max$ size below $20 \mathrm{~mm}$ ) and addition of $10 \%, 15 \%$ and $20 \%$ of plastic waste as sand replacement. Their test results indicate 
sharp decrease in slump with increasing the percentage of plastic, this decrease was attributed to the presence of angular and non-uniform plastic particles. In spite of low slump however, the mixture was observed with good workability and declared suitable for application. Their tests also revealed the decrease in fresh and dry density with increasing the plastic waste ratio; however, increase was reported in dry density with time at all curing ages. Decrease in compressive and flexural strength was observed by increasing the waste plastic ratio which can be related to decrease in adhesive strength between plastic waste particles with cement. However, loaddeflection curve of concrete containing plastic waste showed the arrest of propagation of micro cracks which shows its application in places where high toughness is required. The study has shown good workability in spite of low slump but w/c content kept constant in all samples. They should have reduced the water content in order to improve the strength when workability was not an issue.

P. Suganthy et al. [2013] This study investigates the application of pulverized fine crushed plastic (produce from melting and crushing of high-density polyethylene) as replacement of fine aggregate in concrete with varying known percentages. Their main focus was on optimum replacement of natural sand by pulverized plastic sand. Five concrete mixes were produced from specified concrete materials having replacement of coarse aggregate by $0,25,50,75$ and $100 \%$ respectively to study the test graph results of various concrete properties. The results showed increase in water/cement ratio with increase replacement of coarse with plastic particles to achieve desired $90 \mathrm{~mm}$ concrete slump. They have also observed from the results that gradual decrease in strength of concrete specimen for plastic replacement up to $25 \%$ but afterward the decrease in strength is rapid which shows suitable replacement up to $25 \%$ of sand with plastic pulverized sand. They have also concluded after testing of specimen (having different proportion of plastic replacement) for Ultimate and yield strength that each strength decreases with increase replacement of coarse aggregate with pulverized plastic particles. Their study lacks detailed testing of properties of concrete because only compressive strength and w/c ratio tests will not be sufficient to study the matrix as a whole to be suitable for construction. No efforts were made to explore the use of admixtures in controlling of compressive strength reduction in a mix containing pulverized plastics.

Praveen Mathew et al. [2013] They have investigated the suitability of recycled plastic as partial replacement to coarse aggregate in concrete mix to study effect on compressive strength, modulus of elasticity, split tensile strength and flexural strength properties of concrete. Coarse aggregate from plastic was obtained by heating the plastic pieces at required temperature and crushed to required size of aggregate after cooling. Their experimental results shown that plastic aggregate have low crushing (2.0 as compare to 28 for Natural aggregate), low specific gravity (0.9 as compare to 2.74 for Natural aggregate), and density value (0.81 as compare to 3.14 for Natural aggregate), as compare to
Natural coarse aggregate. Their test results were based on $20 \%$ substitution of natural coarse aggregate with plastic aggregate. Increase in workability was reported when slump test for sample was carried out. Volumetric substitution of natural aggregate with plastic aggregate was selected best in comparison with grade substitution. At 400 centigrade temperature Plastic coarse aggregate shown considerable decrease in strength as compare to normal concrete. An increase of $28 \%$ was observed in compressive strength but decrease in split tensile strength and modulus of elasticity was observed. They recommended that with use of suitable admixture @ $0.4 \%$ by weight of cement will improve the bonding between matrix and plastic aggregate; however, they demand more research to address the tensile behavior of concrete prepared with $20 \%$ plastic aggregate.

Raghatate Atul M. The paper is based on experimental results of concrete sample casted with use of plastic bags pieces to study the compressive and split tensile strength. He used concrete mix by using Ordinary Portland Cement, crushed granite stones as coarse aggregate, portable water free from impurities and containing varying percentage of waste plastic bags $(0 \%, 0.2 \%$, $0.4 \%, 0.6 \% 0.8 \%$ and $1.0 \%)$. Compressive strength of concrete specimen is affected by the addition of plastic bags and with increasing percentage of plastic bag pieces compressive strength goes on decreasing (20\% decrease in compressive strength with $1 \%$ of addition of plastic bag pieces). On other hand increase in tensile strength of concrete was observed by adding up to $0.8 \%$ of plastic bag pieces in the concrete mix afterward it start decreasing when adding more than $0.8 \%$ of plastic bags pieces.

He concluded that utility of plastic bags pieces can be used for possible increase in split tensile strength. This is just a basic study on use of plastic bags in concrete. More emphasis was required by varying the shape and sizes of plastic bags to be use in concrete mixes.

\subsection{Materials}

\section{MATERIALS AND METHODOLOGY}

Cement: OPC 33 Grade cement is used and the properties are mentioned in Table 1

Table 1: Properties of Cement

\begin{tabular}{|l|l|}
\hline $\begin{array}{l}\text { Standard Consistency of } \\
\text { Cement Paste }\end{array}$ & $31 \%$ \\
\hline Initial Setting Time & $120 \mathrm{Mins}$ \\
\hline Final Setting Tim & $236 \mathrm{Mins}$ \\
\hline Specific Gravity & 3.10 \\
\hline
\end{tabular}

Fine Aggregate: Locally available natural sand is used as fine aggregate. The properties of fine aggregates are presented in Table 2.

Table 2: Properties of Fine Aggregate

\begin{tabular}{|l|l|}
\hline Parameter & Test Results \\
\hline Specific Gravity & 2.52 \\
\hline Bulk Density: & \\
\hline
\end{tabular}




\begin{tabular}{|l|l|}
\hline $\begin{array}{l}\text { Loose State } \mathrm{Kg} / \mathrm{m}^{3} \\
\text { Compacted } \mathrm{Kg} / \mathrm{m}^{3}\end{array}$ & 1430.00 \\
\hline Silt Content & 1520.00 \\
\hline Water absorption & $0.36 \%$ \\
\hline Bulking of Sand & $1.38 \%$ \\
\hline
\end{tabular}

Coarse Aggregate: Locally available crushed angular $20 \mathrm{~mm}$ nominal size coarse aggregate was used. The properties of coarse aggregate were tested according to IS 383-1970 1970 (Reaffirmed 2011) with following properties.

Table 3: Properties of Coarse Aggregate

\begin{tabular}{|l|l|}
\hline Bulk density (Loose state) & $1400 \mathrm{~kg} / \mathrm{cu} . \mathrm{m}$ \\
\hline $\begin{array}{l}\text { Bulk density (compacted } \\
\text { state) }\end{array}$ & $1640 \mathrm{~kg} / \mathrm{cu} . \mathrm{m}$ \\
\hline Specific gravity & 2.62 \\
\hline Water absorption & $0.48 \%$ \\
\hline
\end{tabular}

Water: The normal portable water has been used for casting and curing purpose.

Plastic: Locally available granular plastic waste is collected and graded as per requirement. The Fig 1 represents granulated plastic particle used for testing.

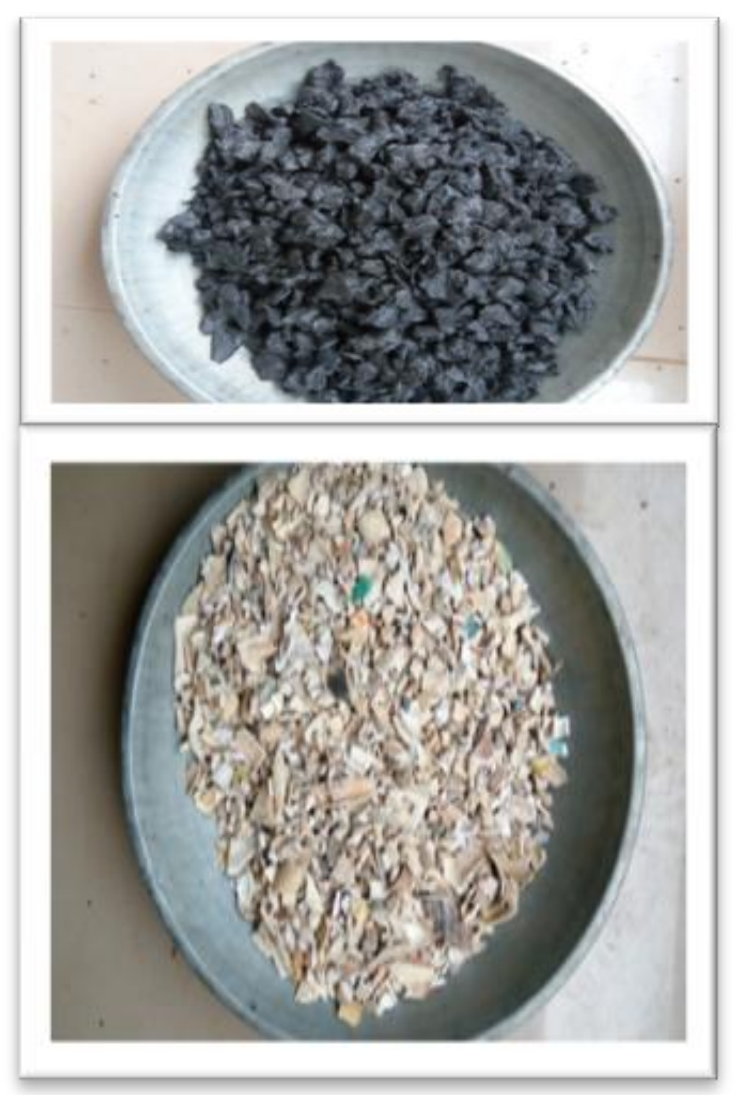

Mix Design: Weight batching method was used and four batches were obtained. Mass substitution of sand with plastic particles was made at percentages of $0 \%, 10 \%$, $20 \%$ and $30 \%$ for the four batches respectively. The water content was kept constant for all the batches. Mix ratio adopted was grade M20. The Table 4 outlines the mix proportions by mass of each batch.
Table 4: M20 Mix Proportions

\begin{tabular}{|c|c|c|}
\hline Ingredients & Quantity & Unit \\
\hline Cement & 300 & $\mathrm{~kg} / \mathrm{m}^{3}$ \\
\hline Water & 153.26 & $\mathrm{~kg} / \mathrm{m}^{3}$ \\
\hline Fine Aggregate & 733.31 & $\mathrm{~kg} / \mathrm{m}^{3}$ \\
\hline Coarse Aggregate & 1260.46 & $\mathrm{~kg} / \mathrm{m}^{3}$ \\
\hline Water Cement Ratio & \multicolumn{2}{|c|}{0.55} \\
\hline
\end{tabular}

\section{IV.RESULTS AND DISCUSSION}

\subsection{Sieve Analysis}

\subsubsection{Sieve analysis for sand}

Sand used for the study is within the limits of BS 882-1992. Its grading curve is in the envelope of maximum and minimum curves as shown in Figure 2.

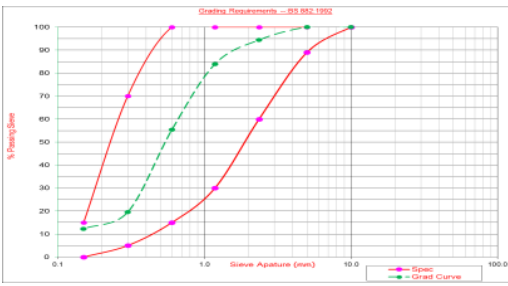

Fig 2: Particle distribution for sand 4.1.2 Sieve analysis results of plastic particles The granulated plastic particles used for this study conform to the requirements BS 882-1992. Their grading curve is within the grading envelop of good fine aggregates although they were coarser than sand as the curve is more to the right of the envelope as shown in Figure 3.

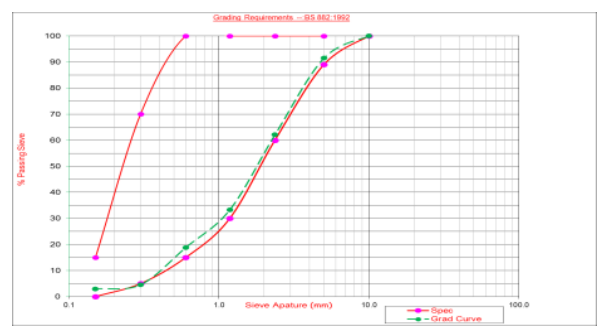

Fig 3: Particle distribution for Plastic Particles

4.1.3 Sieve analysis results for coarse aggregates

The Coarse aggregates particle distribution is shown in Figure 4.

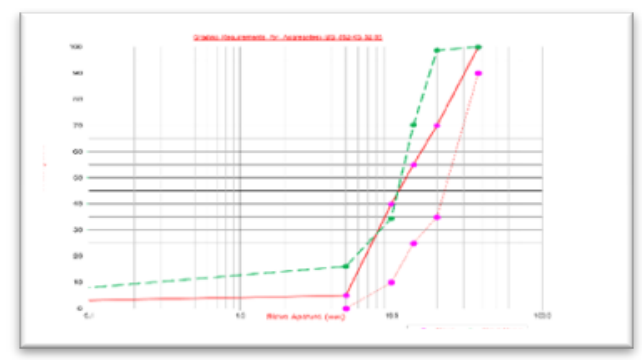

Fig 4: Particle distribution for Coarse Aggregate 4.2 Specific Gravity of Plastic Aggregate

Specific gravity pertains to the relative density of the solid material making up the constituent particles not including the pore space within the particles that is accessible to water. 
The results are presented in Table 5 above show that the plastic particles are lighter than natural soil. This indicates that a lighter concrete was achieved when sand was replaced by plastic aggregates.

Table 5: Specific Gravity of Fine Aggregates

\begin{tabular}{|c|c|}
\hline Type of sample & Specific gravity \\
\hline Natural fines & 2.68 \\
\hline Plastic particles & 0.90 \\
\hline
\end{tabular}

\subsection{Workability}

\subsubsection{Slump}

Reduction of slump with increasing amount of plastic is observed in the concrete. Table 6 illustrate the slump value at different level of replacement. This indicates that the concrete becomes less workable with an increase in the percentage replacement of sand with plastic particles as fine aggregates, which is attributed to the plastic not mixing well with the other concrete constituents. At $10 \%$ replacement the mix was workable enough at the same water content as the control, it was fairly workable at $20 \%$, while the concrete failed the slump test at $30 \%$ replacement. The results show that the concrete mixes with higher plastic content required higher water content to achieve a reasonable workability and flow characteristics.

Table 6: Slump value at different level of replacement.

\begin{tabular}{|c|c|}
\hline $\begin{array}{c}\text { Percentage } \\
\text { replacement }\end{array}$ & Slump $(\mathbf{m m})$ \\
\hline 0 & 23 \\
\hline 10 & 13 \\
\hline 20 & 8 \\
\hline 30 & 3 \\
\hline
\end{tabular}

\subsection{Dry Density}

The dry density of concrete mix at different level of replacement is presented in Table 7.

\subsection{Compressive Strength}

In this study the values of compressive strength for different replacement of plastic contents $(0 \%, 10 \%, 20 \%$ and $30 \%$ ) at the end of different curing periods (7days, and 28 days) as given in Table 8. The Fig 5 represent varying strength of concrete cubes in each of various percentages of sand replacement with plastic particles for 7 days. From the graph above, there is gradual decrease in compressive strength from $0 \%-10 \%$ sand replacement with a decrease of about $0.3 \mathrm{~N} / \mathrm{mm}^{2}$. Between $10 \%-20 \%$ sand replacement the slope becomes less steep with a decrease of $0.2 \mathrm{~N} / \mathrm{mm}^{2}$. Above $20 \%$ the compressive strength has the steepest slope with a decrease of $6.2 \mathrm{~N} / \mathrm{mm}^{2}$ from $20 \%$ to $30 \%$. Fig 6 shows that the compressive strength at 28 days decreases by 8.3, $18 \%$, and $33 \%$ compared to ordinary mix. Therefore, the compressive strength decreases with every addition of plastic content replacing sand at all ages although the strength of all mixtures continued to increase with the age.
Table 7: Dry Density of Concrete Mix

\begin{tabular}{|c|c|c|c|c|}
\hline \multirow{2}{*}{$\begin{array}{c}\text { Percentage } \\
\text { replacement }\end{array}$} & \multicolumn{2}{|c|}{$\begin{array}{c}\text { Cube } \\
\text { Average weight } \\
\text { and density }\end{array}$} & \multicolumn{2}{c|}{$\begin{array}{c}\text { Cylinder } \\
\text { Average weight } \\
\text { and density }\end{array}$} \\
\cline { 2 - 5 } & $\begin{array}{c}\text { Weight } \\
(\mathrm{Kg})\end{array}$ & $\begin{array}{c}\text { Density } \\
\left(\mathrm{KG} / \mathrm{M}^{3}\right)\end{array}$ & $\begin{array}{c}\text { Weight } \\
(\mathrm{Kg})\end{array}$ & $\begin{array}{c}\text { Density } \\
\left(\mathrm{KG} / \mathrm{M}^{3}\right)\end{array}$ \\
\hline 0 & 3.0 & 3000 & 12.65 & 2386.15 \\
\hline 10 & 2.7 & 2700 & 12.45 & 2348.42 \\
\hline 20 & 2.375 & 2375 & 12.35 & 2329.56 \\
\hline 30 & 2.075 & 2075 & 10.5 & 1980.60 \\
\hline
\end{tabular}

Table 8: Compressive strength

\begin{tabular}{|c|c|c|}
\hline $\begin{array}{c}\text { Percentage } \\
\text { replacement }\end{array}$ & $\begin{array}{c}\mathbf{7} \text { days } \\
\text { Compressive } \\
\text { strength } \\
\left(\mathbf{N} / \mathbf{m m}^{\mathbf{2}}\right)\end{array}$ & $\begin{array}{c}\mathbf{2 8} \text { days } \\
\text { Compressive } \\
\text { strength } \\
\left(\mathbf{N} / \mathbf{m m}^{\mathbf{2}}\right)\end{array}$ \\
\hline 0 & 12.5 & 27.25 \\
\hline 10 & 12.2 & 25.00 \\
\hline 20 & 12.0 & 21.00 \\
\hline 30 & 5.8 & 12.25 \\
\hline
\end{tabular}

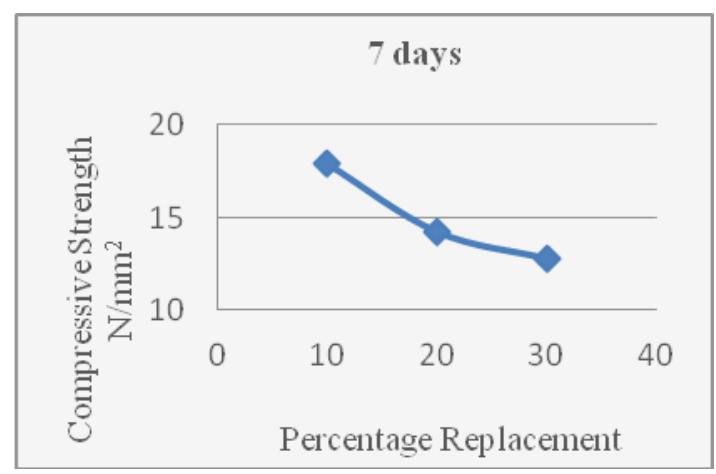

Fig. 5: 7 days compressive strength $\mathrm{V} / \mathrm{s}$ percentage replacement of sand with plastic particles in concrete

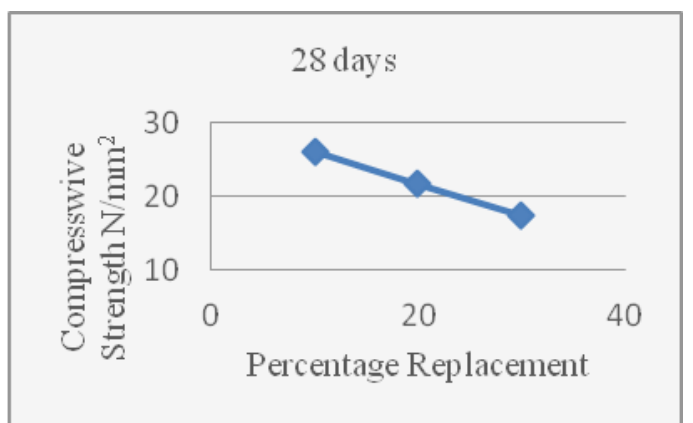

Fig. 6: 28 days compressive strength $\mathrm{V} / \mathrm{s}$ percentage replacement of sand with plastic particles in concrete

\subsection{Split Tensile Strength}

The tensile strength of the mix and graph are presented in Table 9. It was found that split tensile strength of concrete containing plastic (using 10\%, 20\% and $30 \%$ replacement percentages with fine aggregate and a w/c of 0.5) depended on the percentage plastic used. The 
variation of split tensile strength was shown in the above table.

Comparing with the control mix, split tensile strength reduced by $29 \%, 38 \%$, and $66 \%$ with respect to different replacement levels of sand with foundry sand at 7 days. At 28 days the split tensile strength reduces by $8 \%$, $27 \%$ and $68 \%$ from control mix without plastic to the various replacement of sand with plastic.

Table 9: Split tensile strength

\begin{tabular}{|c|c|c|}
\hline $\begin{array}{c}\text { Percentage } \\
\text { Replacement }\end{array}$ & $\begin{array}{c}\text { Beam Load } \\
(\text { KN) }\end{array}$ & $\begin{array}{c}\text { Flexural } \\
\text { Strength }\end{array}$ \\
\hline 0 & 1360 & 0.68 \\
\hline 10 & 1220 & 0.61 \\
\hline 20 & 780 & 0.39 \\
\hline 30 & 480 & 0.24 \\
\hline
\end{tabular}

4.7 Flexural Strength

The flexural strength results of concrete specimen for 28 days are presented in Table 10. The flexural strength of the concrete decreases with every percentage increase of plastic in the mix.

Table 10: Flexural Strength

\begin{tabular}{|c|c|c|}
\hline $\begin{array}{c}\text { Percentage } \\
\text { replacement }\end{array}$ & $\begin{array}{c}\mathbf{7} \text { days Split } \\
\text { Tensile } \\
\text { strength } \\
\left(\mathbf{N} / \mathbf{m m}^{\mathbf{2}}\right)\end{array}$ & $\begin{array}{c}\text { 28 days Split } \\
\text { Tensile } \\
\text { strength } \\
\left(\mathbf{N} / \mathbf{m m}^{\mathbf{2}}\right)\end{array}$ \\
\hline 0 & 1.70 & 2.62 \\
\hline 10 & 1.20 & 2.41 \\
\hline 20 & 1.06 & 1.91 \\
\hline 30 & 0.57 & 0.85 \\
\hline
\end{tabular}

\section{CONCLUSIONS}

From the above study it can be concluded that postconsumer products and industrial waste products/byproducts can be successfully used in concrete to replace coarse or fine aggregates. However, there is decrease in workability and compressive strength of the concrete resulting in the concrete so produced not to be used for structural purposes. However, the structural properties need to be enhanced by using suitable chemical/mineral admixtures. The accelerated carbonation studies to understand the durability of concrete produced with plastic waste, scanning electron microscopy to understand the concrete matrix and pores created due to plastic waste in concrete mix and the fire resistance tests are the most important tests which need to be performed to understand the behaviour of structural concrete produced with plastic waste.For a given water content, the use of plastics in the mix lowers the density, compressive strength and tensile strength. Plastics can be used to replace the Fine / Coarse aggregates in a concrete mixture. This contributes to reducing the unit weight of the concrete. This can be very applicable when requiring lightweight concrete. From observation of the mix, the cement paste and plastic aggregates did not mix as well as the natural aggregates leading to a formation of a weak bond between the two, hence the failure of concrete occurs under lower stresses compared to the control due to failure of the bond. Plastic aggregates can be used to cool the inside of buildings in areas of high temperatures because it does not conduct heat.Scope for Future Study, The use of plastic in concrete lowered its resultant strength, therefore research should be done to come up with methods of overcoming this drawdown before the use of plastic can actively be adopted in concrete construction. The use of plastic in concrete is a new technology on which a lot of research is required.

\section{REFERENCES}

[1] United Nations environment programme 2009, "converting plastic waste in a resource", Industry and economics international environmental technology centre Osaka/ Shil

[2] R. Siddique 2008, "Waste materials and by products in concrete", Springer- Verlag Berlin, Thapar University India.

[3] Bahoria B.V, Parbat D.K and Naganaik P.B (2013), "Replacement of Natural sand in Concrete by Waste products", Journal of Environmental Research and Deveopment.

[4] Batayneh, M, Marie, I, Asi I,(2007) "Use of selected waste materials in concrete mixes". Waste Management.

[5] Choi, Y.W, Moon, D.J, Chung, J.S, Cho, S.K, (2005). "Effects of waste PET bottles aggregates on properties of concrete". Cement and concrete Research.

[6] Al-Manaseer, A.A, T.R, Dalal, (1997) "Concrete containing plastic aggregates", concrete international.

[7] Marzouk, O.Y Deilly R.M, (2007) "valorization of postconsumer waste plastic incementitious concrete composite". Waste Management.

[8] Naik, T.R, Singh, S.S, Bro dersen, B.S, (1996). "Use of postconsumer waste plastics in cement-based composites". Cement and concrete Research.

[9] William H. Langer,Lawrence J. Drew, Janet S. Sachs (2004). "Aggregates and the Environment", American Geological Institute.

[10] Website: www.ijetae.com (ISSN 2250-2459, Volume 2, Issue 6, June 2012) 42

[11] "Experimental Investigation on the Properties of Concrete With Plastic PET (Bottle) Fibre as Fine Aggregates”. Ms. K.Ramadevi1, Ms. R. Manju . 